Прегледни чланак

342.722:35.077.2(497.11)

doi:10.5937/zrpfns54-23384

Renata R. Bjelica, Ph.D. Student

University of Belgrade

Faculty of Law Belgrade

renata.bjelica@ustavni.sud.rs

\title{
ORAL PUBLIC HEARING IN AN ADMINISTRATIVE DISPUTE
}

\begin{abstract}
The right to an oral public hearing is covered by the right to a fair trial as a right guaranteed by the European Convention for the Protection of Human Rights and Fundamental Freedoms as well as by the Constitution of the Republic of Serbia. In this sense, the Law on Administrative Disputes prescribes a rule for the court to establish the facts at an oral public hearing. This law prescribes exceptions to the rule, as well as cases in which the court will "always" and in which it is "obliged" to hold an oral public hearing. Analyzing the legal provisions, with reference to the relevant administrative and constitutional caselaw, and considering the present organization and capacity of the administrative judiciary, the author pointed to certain shortcomings of legislative solutions and administrative judicial decisions, and based on the conclusions drawn, tried to offer possible solutions so that, when it comes to holding a hearing before a court, a higher degree of fairness of trial could be achieved.
\end{abstract}

Keywords: right to a fair trial, Law on Administrative Disputes (ZUS), right to an oral public hearing

\section{INTRODUCTION}

The previously applicable Law on Administrative Disputes ${ }^{1}$ prescribed that the court "as a rule" resolves a dispute on the basis of the facts established in an administrative proceedings (Article 38). The court had the opportunity to hold an oral public hearing because of the complexity of the matter in dispute or, if the court found it necessary to better clarify the state of the matter, the party could

\footnotetext{
${ }^{1}$ Law on Administrative Disputes, Official Gazette of the FRY, no. 46/96.
} 
propose holding of an oral public hearing (Article 33). The aforementioned legal solution is often highlighted as the greatest drawback of this law. ${ }^{2}$

Deciding on the basis of the facts established at the oral public hearing represents one of the elements envisaged by the effective ZUS ${ }^{3}$ related to the fairness of trial in administrative dispute (alongside the decision of the court on the basis of law and decision of the court within a reasonable time). Such determination by the legislator is a consequence of the need to implement European standards of fairness into positive legislation, but it should be mentioned that when ratifying the European Convention for the Protection of Human Rights and Fundamental Freedoms $\mathrm{s}^{4}$ the reserve was placed precisely with regard to the obligation to hold an oral hearing in an administrative dispute, which was justified by the insufficient capacity of the administrative judiciary. ${ }^{5}$

Given the exceptions to the rule prescribed by law, as well as the specific legal formulations governing oral public hearings, it seems that there is still room to consider whether oral public hearings in an administrative dispute are indeed the rule. Namely, the subject of this paper was addressed by numerous writers and practitioners in the field of law, mostly in the period after the entry into force of the ZUS, therefore the initial basis of this paper represent certain conclusions drawn, as well as the formed sentences from the reasoning of court decisions. However, in the paper we have tried to "check" through the analysis of legal provisions and the presentation of the administrative practice in recent times whether in the meantime to which extent the changes occurred with regard to the publicity of the administrative proceedings.

${ }^{2}$ Ljubodrag Pljakić, Praktikum za upravni spor sa komentarom, sudskom praksom $i$ obrascima za primenu u praksi (Practicum for administrative disputes with commentary, case-law and and forms for practical implementation), Belgrade 2011, 298, "Case law based on the application of the previous Law by refusing to establish the facts at the hearing, repeatedly annulled the decision of the respondent authority, delaying the provision of complete protection to the plaintiff so that court protection, when it arrived, was often too late. The plaintiff thus obtained only moral satisfaction, while the damage caused by an unlawful decision after several years of trial was usually not remedied."

${ }^{3}$ Law on Administrative Disputes - ZUS, Official Gazette of the RS, no. 111/09.

${ }^{4}$ European Convention for the Protection of Human Rights and Fundamental Freedoms Convention, Official Gazette of Serbia and Montenegro - International Treaties, no. 9/03, 5/05, 7/05, Official Gazette of the RS - International Treaties, no. 12/10 and 10/15.

5 Зоран Лончар, „Примена европских стандарда у управном спору у Србији“, Правни животи бр. 5-6/2013, 91, 93 ("Implementation of European Standards in Administrative Disputes in Serbia") "At that point, there were eighteen judges in the administrative department of the then Supreme Court of Serbia, six judges in the administrative department of the Belgrade District Court, and three judges in Novi Sad, while in all other district courts in Serbia, no separate administrative departments were formed, but in administrative cases, judges, assigned in civil law matters, acted as needed." 


\section{RIGHT TO ORAL PUBLIC HEARING AS A PART OF THE RIGHT TO A FAIR TRIAL}

The right to a fair trial under Art. 6 of the Convention guarantees that everyone, while deciding on their civil rights and obligations or on the criminal charge against them, has the right to a fair and public hearing within a reasonable time before an independent and impartial tribunal established by law, as well as the right to a public verdict, with the possibility of excluding the press and the public from all or part of the trial when necessary in the interest of morals, public order or national security in a democratic society, when required by the interests of a minor or the protection of the privacy of the parties, or to the extent that the court deems appropriate, necessary in particular circumstances where the public could harm the interests of justice (item 1). Item 2 of the said Article establishes the presumption of innocence, while Item 3 of this Article covers the minimum rights belonging to anyone charged with a criminal offence.

It follows from the aforementioned Convention provisions that the right to a fair trial encompasses the rights explicitly stated in Art. 6, as well as that the guarantees provided refer to the proceedings in which civil rights and obligations and criminal charges are decided. However, by applying teleological interpretation, new norms were established as an integral part of the right to a fair trial, so that the right to a fair trial becomes a system of explicit and implicit rights, and all these rights, expressed through the practice of the European Court of Human Rights, include the following: the right of access to courts, the right to a court established by law, the right to independence and impartiality in a trial, the right to legal assistance, the right to procedural equality of parties, the right to a public hearing, the right to adversarial proceedings, the right to a reasoned decision, the right to a trial within a reasonable time, the right to a public judgement, the right to effective enforcement of the judgement, the prohibition of arbitrary proceedings and the right to legal certainty. ${ }^{6}$

On the other hand, by autonomous concepts ${ }^{7}$ of the notions: court, civil rights and obligations and criminal charges it was made possible to extend the European standard of fairness, among others, to administrative disputes.

The right to a public hearing belongs to the corpus of rights expressly embodied in Art. 6. of the Convention and covers two rights. One right is the right of the press and the public to attend the trial. This right is not absolute and may

\footnotetext{
${ }^{6}$ Katarina Golubović, „Европски стандарди правичности у управном законодавству и пракси“ ("European Fairness Standards in Administrative Legislation and Jurisprudence"), PhD Thesis, Belgrade 2015, 45.

${ }^{7}$ On the notion of autonomous concepts see. Драгољуб Поповић, „Аутономни концепт европског права људских права“ (“An Autonomous Concept of European Human Rights Law”), Анали Правног̄ факулӣет̄а у Беог̄раду, Београд 2009, 121-137.
} 
be excluded with an aim to protect certain interests. "The public nature of the debate offers the opportunity to protect the parties to the dispute from the secret administration of justice without public scrutiny, and to maintain public confidence in the justice process and in the courts themselves." 8 The second right involves the direct involvement of the parties to the proceedings, with respect for their equality and with the opportunity for each party to provide their statement on all relevant issues and evidence.

This Article provides for the right of everyone to have an independent, impartial and legally established court, in a fair and reasonable time, to publicly hear the case and decide on their rights and obligations, the merits of the suspicion that gave rise to the proceedings, as well as the charges against them, as well as that the public can be excluded for the entire duration of the proceedings before a court or in a part of the proceedings, only to protect the interests of national security, public order and morals in a democratic society, as well as to protect the interests of minors or privacy of the parties, in accordance with the law.

\section{ORAL PUBLIC HEARING IN ACCORDANCE WITH THE ZUS}

The fairness of a trial in an administrative dispute is prescribed by Art. 2 of the ZUS and it covers the court's decision in accordance with the law and within a reasonable time, based on the facts established at the oral public hearing.

Therefore, the effective ZUS sets forth the rule that in an administrative dispute the court shall decide on the basis of the facts established at the oral public hearing (Article 33, paragraph 1).

\subsection{Public and oral nature of the hearing}

The ZUS stipulates that the hearing before the court is public, with the possibility of excluding the publicity, for the same reasons for excluding the publicity as established by the Constitution and the Convention.

When it comes to oral hearing, the ZUS contains provisions governing the scheduling of the hearing, the conduct of the hearing, the course of the hearing and the consequences of the parties' absence from the hearing. In summary, these provisions (Articles 36-39) stipulate that the Trial Chamber decides to hold the hearing, that is, the decision not to hold the hearing shall be made in a non-public hearing of the Chamber Panel; that the President of the Chamber determines the date of the hearing to which the parties and interested parties are invited and that the President of the Chamber chairs the debate; that the minutes of the hearing are

\footnotetext{
${ }^{8}$ К. Голубовић, 154. The right to a fair trial has been established by Art. 32 st. 1 and para. 3 of the Constitution of the Republic of Serbia .
} 
taken; that the hearing may be postponed only for important reasons, as decided by the Chamber with the prescribed consequences of the parties' absence from the oral public hearing and the course of the hearing.

It is important to note that Art. 74 of the ZUS prescribes the relevant application of the provisions of the Law on Civil Procedure ${ }^{9}$ to all issues of the administrative dispute settlement procedure which are not regulated by the ZUS. The provisions applied accordingly means an adjusted application of the provisions of the procedural law governing litigation to an administrative matter settlement procedure, that is, the provisions of the Law on Civil Procedure are applied to the administrative procedure only unless otherwise expressly prescribed by the ZUS and only when such application is in accordance with the nature and peculiarities of administrative dispute.

\subsection{Holding a hearing}

The ZUS provides for an exception to the rule that facts be established at an oral public hearing. This exception applies to the case where the subject matter of the dispute is such that it clearly does not require a direct hearing of the parties and an independent establishing of the facts, or if the parties expressly agree to it, whereby the court is obliged to specifically state the reasons for not holding an oral hearing (Art. 33, par.2 and par.3 of the ZUS). It could be said that the stated legal wording does indeed relativize the formally proclaimed rule on holding an oral public hearing. ${ }^{10}$ This is because the mentioned legal provision provides broad discretion for the court to evaluate the nature of the subject matter of the dispute.

What would be the subject matter of the dispute, which clearly does not require a direct hearing of the parties and an independent establishing of the facts? We believe that the above wording indicates, for example, the situation where the lawsuit does not dispute the facts, but emphasizes the violation of the rules of procedure or the application of substantive law, or refutes the facts, which in administrative proceedings was established on the basis of the findings and opinion of expert witnesses. The mentioned attitude is further corroborated by the administrative case law as set out below (Administrative Court Judgement 4 U. 19401/17 of 23 February 2018 and the Administrative Court Judgement - Niš Division II-9 U. 8590/15 of 19 November 2015).

The ZUS prescribes cases in which the hearing will always be held, as well as those in which it is mandatory to hold the hearing. The hearing will always be held due to the complexity of the subject matter of the dispute, or for better clar-

${ }^{9}$ Law on Civil Procedure, Official Gazette of $R S$, no. 72/11, 49/13 - Constitutional Court Decision, 74/13 - Constitutional Court Decision, 55/14 and 87/18.

${ }^{10}$ Драган Милков, „О управном спору у Србији“ (“On Administrative Dispute in Serbia”), Collection of Papers of the Faculty of Law in Novi Sad 3/2011, 132. 
ification of the state of affairs, as well as in cases where the defendant fails to submit the case files to the court even after the second request of the court, or if they declare that they cannot submit them (Art. 34, par.1). The obligation to hold a hearing refers to administrative matters participated by two or more parties with opposite interests and when the court determines the facts for deciding in full jurisdiction (Art. 34 (2) of the ZUS).

The used terms 'always' and 'mandatory' raise the question of whether the two cases differ merely on a linguistic or substantive level. We believe that in this particular case it is a substantive difference. Namely, the wording of Art. 34 par. 1 concerning the complexity of the case and the better clarification of the matter, would entail the discretion of the court to evaluate whether the administrative matter is complex, or whether its clarification is needed, and depending on this discretion of the court an oral public hearing would be held, the decision would be passed without holding a hearing. When it comes to holding an oral public hearing in the event of non-compliance with the obligation to file a Statement of Defence and the case file, it is emphasized that there is no discretion of the court and that the court is under an obligation to hold a hearing as soon as the condition, that the files are required twice, is fulfilled. ${ }^{11}$ However, there may be cases where the court could resolve the administrative dispute without case files and without holding a public hearing, as we will see in the part relating to the relevant case law, which implies that in this case also the holding of an oral public hearing, under certain conditions, would not be mandatory. At this point we would also point out that "in the case-law, it has emerged as a contentious situation whether the court should hold an oral hearing within the meaning of Article 30, paragraph 3 of the ZUS, when the plaintiff files an orderly lawsuit due to non-response of the administration, and the respondent authority even after the second request of the court (duly served upon it) does not file a Statement of Defence and the case files to the court. In view of the aforementioned situation, a judicial attitude was made that the lawsuit filed for failure to pass a decision is deemed grounded and the court decides on the lawsuit without holding an oral public hearing, if the plaintiff acted in the manner prescribed by law before filing the lawsuit, and the respondent authority did not file a Statement of Defence and the case files to the court even after the second request." 12

On the other hand, the wording of Art. 34 par. 2 indicates the mandatory holding of the hearing, without any discretion of the court to decide on its holding.

Finally, the question arises as to whether a court may not hold an oral public hearing in cases where the parties expressly consent to it, yet it is a statutory

11 љ. Пљакић, 302.

12 Зорана Брајовић, „Спорна правна питања у вези примене Закона о управним споровима“" (Disputed Legal Issues Regarding the Application of the Law on Administrative Disputes), Билйен Уӥравног̄ суда 3/2011, 445. 
obligation to hold an oral public hearing. We believe that this is not possible, that is, such conduct would constitute a significant violation of the Rules of Procedure. ${ }^{13}$

In conclusion, when it comes to holding an oral public hearing, in an administrative dispute, the court decides on an objection filed against a sole judge's decision dismissing a claim as disorderly and for other legal reasons (Art. 25 and Art. 26), after an oral public hearing and only if the complainant required holding a hearing. The court decides on the request for postponement of the execution of the final administrative act, by which the decision on the merits was decided in the administrative matter, without holding a hearing (Art. 23 of the ZUS).

\section{RELEVANT CASE LAW}

\subsection{The statutory obligation to hold a hearing}

\subsubsection{Multiparty administrative matters}

Analyzing the relevant administrative case-law of recent date, we can conclude that court cases in which an oral public hearing was held relate primarily to the holding of an oral public hearing which was mandatory in accordance with law, or to proceedings involving two or more parties with opposing requests. Such are, for example, procedures for placing a minor child in a foster family, ${ }^{14}$ under guardianship,${ }^{15}$ deciding on the legality of a decision of the High Court Council which upheld an appeal by a Disciplinary Prosecutor by adopting a motion for disciplinary action against a judge, ${ }^{16}$ or for unauthorized use of public owned land. ${ }^{17}$

\subsubsection{Full jurisdiction}

An administrative dispute of full jurisdiction is one in which the court is empowered, under legal conditions, and in certain cases prescribed by law, to go further than considering the lawfulness of an administrative act and its annulment in the event of establishing its unlawfulness. ${ }^{18}$ Namely, in a dispute of full jurisdiction, the court goes beyond establishing the unlawfulness of the impugned administrative act, by passing a meritory judgement settling the administrative

\footnotetext{
${ }^{13}$ Јелена Ивановић, „Утврђивање чињеница у управном спору“ (Establishing the facts in an administrative dispute), Билеиен Уйравног суда 3/2011, 384.

${ }^{14}$ Judgement of the Administrative Court-Division in Niš II-3 U. 4396/17 of 10th May, 2018.

15 Judgement of the Administrative Court 17 U. 2600/16 of 19th May, 2017.

${ }^{16}$ Judgement of the Administrative Court 15 U. 11078/17 of 22nd June, 2018.

17 Judgement of the Administrative Court-Division in Kragujevac I-4 U. 18343/16 of 8th June, 2018.

18 Зоран Томић, Коменйар Закона о уиравним сйоровима, (Commentary on the Law on Administrative Disputes), Official Gazette 2012, 627.
} 
matter after ruling that it should be annulled, whereby such a judgement supersedes the annulled administrative act in its entirety. The full jurisdiction dispute, when it comes to our administrative case-law, is an extremely rare way of ruling by the court. ${ }^{19}$

With reference to establishing the facts in a full jurisdiction dispute, the ZUS prescribes the mandatory holding of a hearing when the court rules in full jurisdiction. Analysis of the administrative case-law shows that in most cases the Administrative Court has ruled in the full jurisdiction, when a dispute referred to the protection of a voting right. Namely, the Administrative Court, when deciding on the appeals of the councillors, passed judgements approving the appeals and confirming the therm of their office or determining the termination of the office of the local councillors of individual units of local self-government. Thus, in its decisions, the court itself resolved these electoral matters (which is explicitly stated in the reasoning of the court judgements), without any hearing being held. ${ }^{20}$

The above stated may be explained in the following manner. By the provision of Art. 54 par. 3 of the Law on Local Elections ${ }^{21}$ it is stipulated that in the procedure for the protection of electoral rights the court applies accordingly the provisions of the law governing proceedings in administrative disputes. Therefore, the court applies only those provisions of the ZUS, and to the extent that is appropriate to the legal nature of the electoral procedure. As the procedure for the protection of electoral rights provided for by the electoral legislation sets forth short deadlines for the acting by both the electoral commission and the court, the application of the ZUS accordingly, enables the court to decide in its full jurisdiction without necessarily holding an oral public hearing. On the other hand, a question could be raised whether the above provision of the Law on Local Elections derogates in some way the provision of the ZUS, which stipulates that, with regard to the application of the provisions of the ZUS, other acts are adjusted to the administrative act, and that such acts may be subject to administrative disputes (Article 3, paragraph 4 of the ZUS). Therefore, this ZUS provision does not indicate the appropriate application of its provisions regarding the administrative protection of other final individual acts in respect of which the law provides for protection in an administrative dispute. We believe that the answer to the above question depends on the circumstances of whether in the particular case the preference should be given to the effective conduct of the electoral procedure vis-à-vis the public nature of the administrative proceedings. Holding an oral public hearing in an administrative dispute could complicate the electoral process, and we believe that prescribing the appropriate application of the ZUS also provides for adequate protection of the electoral right.

\footnotetext{
${ }^{19}$ For more on the full jurisdiction administrative dispute, see Вук Цуцић, „Уӣравни сйор йуне јурисдикиије -модели и врсйе“" (Administrative Dispute of Full Jurisdiction-Models and Types), Belgrade 2016, 261-264.

${ }^{20}$ Administrative Court Judgement 5 Už. 713/12 of 25 October 2012, Judgement of the Administrative Court-Section in Kragujevac I-2 Už. 194/2018 of 3 October, 2018.

${ }^{21}$ Law on Local Elections, Official Gazette of RS, no. 129/07, 34/10 and 54/11.
} 


\subsection{Ruling by the court on the need to hold a hearing}

\subsubsection{Complexity of the case}

Searching through the case law of the Administrative Court the author of this paper found only one case of holding a hearing due to the complexity of the administrative case. ${ }^{22}$ Namely, the judgement of the Administrative Court upheld the plaintiff's lawsuit and annulled the decision of the Commission for Protection of Competition which had established a violation of competition embodied in the conclusion of a restrictive agreement, which was not exempted from prohibition; and that the restrictive agreement was prohibited and annulled and the participants were imposed administrative measures of protection of competition in the form of a pecuniary obligation.

However, we believe that the above example requires additional analysis. Specifically, in this particular case, the Plaintiff claimed that she did not conclude a business-technical cooperation agreement, that is, she did not sign it, and that she was not in a contractual relationship with the other contracting party, and that the only business transaction the Plaintiff had with the other the contractual party was a one-off delivery of three products, but not on the basis of a business-technical cooperation agreement. Considering that the court had before it the lawsuit, the statement of defence, the business and technical cooperation agreement, the delivery note for the delivery of the three products listed, the files of the Commission for Protection of Competition on the conducted procedure, the question is what made this administrative dispute complex. This question is justified especially given the fact that in other competition cases ${ }^{23}$, which also challenge the decisions of the Commission for Protection of Competition establishing the conclusion of prohibited agreements, with several plaintiffs, with far more market participants and the number of contracts concluded, and with hundreds of times higher values of imposed administrative measures, and in which the plaintiff even filed the request for the court to rule on the merits of the matter, therefore in full jurisdiction, no hearing was held. Namely the Court did not find that the complexity of the case required a hearing.

The aforementioned analysis indicates that the determination of the legislator to give the discretion to the court to evaluate the complexity of the administrative matter, and therefore decide on the obligation to hold a hearing, is not the best solution. We believe that, given the importance of exercising the right to hold a hearing as part of a broader right to a fair trial, in relation to governing the mandatory hearing, it is necessary to exclude by law he use of vague and relative notions (what may be complex to one judge, is not necessary the same to another) and, instead, precisely state exceptions to the mandatory holding of hearing.

\footnotetext{
22 Judgement of the Administrative Court 22 U. 4016/16 of 26th October, 2016.

${ }^{23}$ Judgement of the Administrative Court 17 U. 181/18 of 22nd March, 2018.
} 


\subsubsection{Failure to submit case files}

The ZUS stipulates the obligation of the respondent to submit to the court all the files related to the subject of the administrative dispute within the given deadline, as well as to file a statement of defence, and in the event that the defendant does not submit the case files within eight days after the second request, or if he declares that he cannot deliver them, the court may settle the dispute without a case file, whereby it will establish the facts at the hearing (Art. 30 par.3). It follows from the above legal provision that in the said case, holding an oral public hearing is necessary when the facts are disputable, as indicated by the Judgement of the Administrative Court 7 U. 20516/10 of 14th July 2011, stating that "a court may exceptionally resolve a dispute in a unilateral administrative matter without having access to the files relating to the subject of the administrative dispute and without holding an oral public hearing, if from the allegations of the lawsuit and the reasoning of the impugned administrative act, it is evident that the facts of the administrative procedure are undeniably established, and that the legality of the impugned administrative act should be evaluated in respect of disputed legal issues or when violations of the rules of administrative procedure that affect the settlement of the matter are evident from the reasoning of the impugned administrative act."

\subsection{Ruling by the court without holding a hearing}

The court ruled without holding an oral public hearing in the largest number of administrative disputes (cases related to tax, citizenship, social security contributions, protection of electoral rights, parliamentary mandates, intellectual property). In the reasoning of the majority of its decisions passed without holding a hearing, the court stated as the reason that the subject of the dispute was such that it clearly did not require direct hearing of the parties and independent establishing of the facts, therefore the court reiterated the legal wording of Art. 33 par. 2, without any further justification. ${ }^{24}$

As an exception to the foregoing paragraph, we can mention a very small number of administrative decisions in which the stated reasoning for not holding a hearing was further supplemented. Such an example would be the judgement of Administrative Court 4 U. 19401/17 of 23rd February 2018 by which the Administrative Court upheld the lawsuit and quashed the decision of the Commission for Protection of Competition which had established the dominant position of a market participant. The said decision was passed without holding a hearing, with the court relying on the provisions of Art. 33 par. 2 of the ZUS arguing that the reason why the hearing was not held was that the impugned decision was based on the

${ }^{24}$ See. website of the Administrative Court www.up.sud.rs - Section of the case-law database. 
established existence of a violation of the rules of procedure by the respondent authority. The identical reasoning is contained in the judgement of the Administrative Court - Niš Division II-9 U. 8590/15 of 19th November 2015, which upheld the lawsuit and annulled the decision of the Faculty of Law of the University of Niš whereby the plaintiff's appeal against the decision on rejecting the request for approval of temporary suspension of rights and obligations in doctoral academic studies was dismissed.

\subsection{Constitutional Court Case-Law}

Concerning the constitutional court case-law regarding the ruling in cases formed on the constitutional complaints filed by the complainants, for challenging the decisions of the Administrative Court, among other things, violated the right to a fair trial because the Administrative Court failed to hold an oral public hearing and justified the lack of a hearing by simple citing the provision of Art. 33 par. 2 of the ZUS, we point out the following:

The Constitutional Court, in its decisions rendered on the basis of the filed constitutional appeals, took the view that the challenged judgements of the Administrative Court provided a constitutionally acceptable justification as to why no oral hearing was held in the particular case, and that such justification was, in the opinion of the Constitutional Court, based on a constitutionally acceptable interpretation of the provisions of Art. 33 par. 2 of the ZUS, because the Administrative Court could have decided to hold an oral hearing, if it considered that it was required due to the complexity or for a better clarification of a specific administrative matter, but was not obliged to do so. ${ }^{25}$

\section{HOLDING OF ORAL PUBLIC HEARING AND ORGANIZATIONAL ISSUES}

When it comes to holding an oral public hearing, two important circumstances should be taken into account. One is that the specificity of the work of the Administrative Court is the fact that almost half of the cases require acting within very short time limits. Particularly urgent are considered both administrative cases where the law prescribes deadlines for acting (the aforementioned Law on Local Elections stipulates that an administrative decision shall be passed within thirty days from the date of submission of the appeal by the councillor), and also administrative cases in which the nature of the administrative matter is such as

${ }^{25}$ Constitutional Court decisions Už-6894/2015 of 19th September 2016; Už- 8397/2015 of 8th November 2016; Už- 1386/2015 of 2nd June 2016. 
to require particularly urgent action (guardianship disputes). The other circumstance concerns the number of cases under processing, as well as the organization and capacity of the administrative judiciary. Namely, the number of cases under processing by the Administrative Court is steadily increasing, which is, inter alia, closely related to the entry into force of the Law on General Administrative Procedure - the ZUP ("Official Gazette of RS", no. 18/16 and 95/18) which, in a different way from the previously effective Law on General Administrative Procedure, defines the concept of an administrative matter (including, inter alia, the conclusion of administrative contracts, the issuance of guarantee acts, the taking of administrative actions and the provision of public services). This necessarily results in an increase in the number of cases under processing by the Administrative Court, bearing in mind that in relation to an objection, as a new remonstrative legal remedy stipulated by the ZUS lodged due to a failure of an authority to fulfill the obligations under an administrative agreement, for undertaking or failing to take an administrative action or for inadequate provision of public services, the court adopts an administrative act in the form of a decision. On the other hand, the domestic administrative judiciary is organized as single-court, with insufficient number of judges (please note that in Austria, for the same area of jurisdiction, or approximately the same population, there are twenty times more judges than is the case here). ${ }^{26}$

These problems are also recognized in the draft version of the Judicial Development Strategy for the period 2019-2024, which stated that special attention should be paid to the organization, capacities and improvement of the work of the Administrative Court, as well as to the manner of regulating the administrative dispute. ${ }^{27}$

It is clear that the above circumstances directly affect the holding of an oral public hearing. Namely, on the one hand, it is necessary to ensure that the court acts within a reasonable time. The right to act within a reasonable time is a right explicitly embodied in the right to a fair trial. On the other hand, the conventional and constitutional guarantee of the right to a fair trial consists, inter alia, in the fact that a decision on one's right or obligation was passed in a procedure with conducting an oral public hearing. In an effort to act within a reasonable time, and in accordance with the statutory rule that facts are established at an oral public hearing, given the current organization and capacity of the Administrative Court, it seems that holding of a hearing is rather an exception than a rule, as indicated by officially published statistics, the review of which is shown below.

\footnotetext{
${ }^{26}$ Добросав Миловановић, В. Цуцић, „Реформа управног судства“ (“Administrative Judicial Reform”), Правни живоӣ бр. 10, 2016, 152.

${ }^{27}$ Draft version of the Judicial Development Strategy for the period from 2019 to 2024, 26, available at:https://www.mpravde.gov.rs, accessed 15th August, 2019.
} 


\subsection{What do the statistics show?}

In 2011, when the Administrative Court started to settle exclusively the newly received cases, out of a total of 12,196 cases resolved, in only 264 cases an oral hearing was held, which makes $2.17 \%$ cases, while in 2012 the number of the held oral hearings increased, but the total percentage of resolved administrative disputes based on the facts established at the oral hearing still does not exceed even a symbolic $10 \%$ of the total resolved cases." 28

From the latest published data ${ }^{29}$ for the six-month period of 2019, when comparing the relationship between deciding in non-public sessions and deciding at oral public hearing, all given the total number of pending cases at the beginning of the reporting period $(37,520)$, we can conclude that the percentage of oral public hearings held did not increase significantly beyond the determination of the jurisdiction of the Administrative Court.

\section{CONCLUSION}

The conclusion of the paper is, in fact, a summary of the conclusions reached by an analysis of the legal provisions and relevant case-law. First of all, most administrative court proceedings in which court decisions were passed after oral public hearings, involved multilateral administrative matters in which oral public hearings are mandatory. In the other analyzed cases, the statutory exception to the oral public hearing in a court decision is justified by simply stating the legal provision that provides for this exception. When it comes to administrative matters in which the court has exercised the discretion to assess the complexity of the administrative matter and decide on the need to hold an oral public hearing, it can be concluded that the case-law is uneven.

We believe that the facts from the foregoing paragraph are a consequence of the shortcomings of legislative solutions. In addition to resolving the organizational issues of the administrative judiciary that will certainly follow, as part of a national strategy for the development of the judiciary, we believe that providing

28 Зоран Лончар, „Примена европских стандарда у управном спору у Србији“ (“Implementation of European Standards in Administrative Disputes in Serbia”) ,, Правни животи бр. 5-6/2013, 91,93.

${ }^{29}$ In the headquarters and units of the Administrative Court, oral public hearings were held in 742 cases, adjourned in 132 cases, cancelled in 20 cases, non-held in 14 cases and scheduled in 243 cases, while the court ruled in non-public sessions in 10,715 cases. The number of unresolved cases at the beginning of the reporting period amounts to 37,520. The six-month report on the work of the Administrative Court by matters for the period from 1st January 2019 to 30th June $2019 \mathrm{Su}$ III-20 10 / 19-3 of 5th July 2019, available on the website of the Administrative Court, accessed 15th August, 2019. 
for provisions in administrative field by which oral public hearings are mandatory or prescribing exceptions to the rules on mandatory public hearings in an administrative dispute, without the use of legal standards and vague terms in such prescribing, would very much contribute to the fairness of the trial in administrative dispute.

\section{REFERENCES}

Brajovic, Zorana, „Sporna pravna pitanja u vezi primene Zakona o upravnim sporovima" ("Disputed legal issues regarding the application of the Law on Administrative Disputes"), Bulletin of the Administrative Court 3/2011.

Golubović, Katarina, „Evropski standardi pravičnosti u upravnom zakonodavstvu i praksi“" ("European Fairness Standards in Administrative Legislation and Jurisprudence" PhD thesis, Belgrade 2015.

Ivanović, Jelena, „Utvrđivanje činjenica u upravnom sporu“ ("Establishing the Facts in an Administrative Dispute"), Bulletin of the Administrative Court 3/2011.

Lončar, Zoran, „Primena evropskih standarda u upravnom sporu u Srbiji“" (“Application of European Standards in Administrative Dispute in Serbia"), Pravni život br. 5-6 / 2013.

Milkov, Dragan, „O upravnom sporu u Srbiji“ (“On Administrative Dispute in Serbia"), Proceedings of the Faculty of Law in Novi Sad 3/2011.

Milovanović, Dobrosav, Cucić, Vuk, „Reforma upravnog sudstva“ (“Administrative Judicial Reform”), Pravni život br. 10, 2016.

Pljakić, Ljubodrag, Praktikum za upravni spor sa komentarom, sudskom praksom $i$ obrascima za primenu u praksi (Practicum for administrative disputes with commentary, case-law and and forms for practical implementation), Belgrade 2011.

Popović, Dragoljub, „Autonomni koncept evropskog prava ljudskih prava“ (“An Autonomous Concept of European Human Rights Law"), Annals of the Belgrade Faculty of Law, Belgrade 2009.

Tomić, Zoran, Komentar Zakona o upravnim sporovima (Commentary on the Law on Administrative Disputes), Official Gazette 2012.

Cucić, Vuk, ,Upravni spor pune jurisdikcije - modeli i vrste“ "Administrative Dispute of Full Jurisdiction-Models and Types", Belgrade 2016.

\section{LEGAL SOURCES}

European Convention for the Protection of Human Rights and Fundamental Freedoms, Official Gazette of Serbia and Montenegro - International Treaties, no. 9/03, 5/05, 7/05, Official Gazette of RS - International Treaties ", no. 12/10 and 10/15. Constitution of the Republic of Serbia, Official Gazette of RS, No. 98/06.

Law on Administrative Disputes, Official Gazette of RS No. 111/09.

Law on Civil Procedure, Official Gazette of RS, no. 72/11, 49/13 - Constitutional Court decision, 74/13 - Constitutional Court decision, 55/14 and 87/18. 
Law on Administrative Disputes, Official Gazette of FRY No. 46/96.

Law on Local Elections, Official Gazette of RS No. 129/07, 34/10 and 54/11.

Judgement of the Administrative Court-Division in Niš II-3 U. 4396/17 of 10th May 2018.

Judgement of the Administrative Court 17 U. 2600/16 of 19th May 2017.

Judgement of the Administrative Court 15 U. 11078/17 of 22nd June 2018.

Judgement of the Administrative Court-Division in Kragujevac I-4 U. 18343/16 of 8th June 2018.

Judgement of the Administrative Court 22 U. 4016/16 of 26th October 2016.

Judgement of the Administrative Court 17 U. 181/18 of 22nd March 2018.

Judgement of the Administrative Court 7 U. 20516/10 of 14th July 2011.

Judgement of the Administrative Court-Division in Kragujevac I-2 U. 194/2018 of 3rd October 2018.

Constitutional Court Decision Už -6894/2015 of 19th September 2016

Constitutional Court Decision Už- 8397/2015 of 8 November 2016.

Constitutional Court Decision Už- 1386/2015 of 2 June 2016.

OTHER SOURCES

Draft version of the Judicial Development Strategy 2019-2024, 26, available at https:// www.mpravde.gov.rs, accessed 15 August, 2019.

The six-month report on the work of the Administrative Court by matters for the period from 1 January 2019 to 30 June 2019 Su III-20 10 / 19-3 of 5 July 2019, available on the website of the Administrative Court www.up.sud.rs, accessed on 15th August, 2019. 


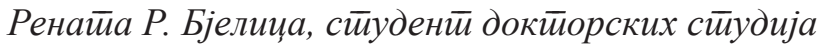

Универзитией у Беог̄раду

Правни факулиетей у Беог̄раду

renata.bjelica@ustavni.sud.rs

\section{Усмена јавна расправа у управном спору}

Сажейак: Право на усмену јавну расирраву обухваћено је иравом на ирравично суђење као ирравом гаранйованим Евройском конвениијом за зашииитиу ьудских иррава и основних слобода и Устиавом Рейублике Србије. У йом смислу је Законом о уйравним сйоровима ирройисано ирравило да суд уйврђује чињенично стйье на усменој јавној расйрави. Овим законом су ироииисани изузеци од наведеног йравила, као и случајеви у којима ће суд „увек“, а у којима је „обавезан“ да одржи усмену јавну расираву. Анализом законских одредаба, уз освриее на релеванйну уйравносудску и устиавносудску ираксу, а имајући

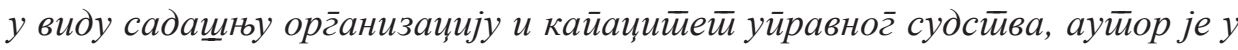
раду указао на одређене мањкавостии законодавних решењ и и уиравносудских одлука, йе на основу изведених закључака йокущао да йонуди мог̄ућа рещењь како би се можда, када је у ииитаюу одржавање расирраве йред судом, мог̄ао

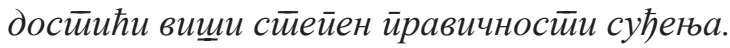

Кључне речи: ираво на ирравично суђење, ЗУС, ираво на усмену јавну расираву

Датум пријема рада: 30.9.2019. 